\title{
China-Pakistan Economic Corridor: Long Term Cooperation in Petro Chemical Industry for Enhanced Oil Recovery
}

\author{
Abdul Latif1 ${ }^{12 *}$, Nazish Akbar ${ }^{3 *}$, Faiza Manzoor ${ }^{1}$ and Fayaz Khan ${ }^{2}$ \\ ${ }^{1}$ Department of Agricultural Economics and Management, Zhejiang University, China \\ ${ }^{2}$ Department of Management Sciences, Abbottabad University of Science and Technology, Pakistan \\ ${ }^{3}$ Institute of China Studies, Zhejiang University, China
}

Submission: January 16, 2018; Published: January 24, 2018

*Corresponding author: Abdul Latif, Nazish Akbar, Department of Agricultural Economics and Management, Zhejiang University, 310029

Hangzhou, Institute of China Studies, Zhejiang University, 310029 Hangzhou, China, Email: Latif_hu117@yahoo.com

\begin{abstract}
In the recent years, oil recovery remains one of the biggest challenges in the world. Especially in developing countries including Pakistan production of petrochemical facilities are not properly installed. Therefore, Pakistan has to import large quantity of oil and oil based products from Middle East countries. This paper presents a review on the existing situation of petrochemical industry in Pakistan and concludes the viability of China-Pakistan cooperation in term of installing EOR technologies and helping Pakistan in mitigating the current energy crisis.

Keywords: Petrochemical; Enhanced oil recovery; CPEC
\end{abstract}

\section{Introduction}

Crude oil and natural gas remain central to the global political economy. However, there is an uneven production, distribution and consumption of oil and gas reserves in the world [1]. Production of petrochemical facilities in developing countries including Pakistan is currently at a low level due to prevailing economic conditions. In developing countries the capacity utilization generally is low also for reasons other than the economic conditions and market limitations [2]. Pakistan economy is growing steadily. This growth demands higher energy consumption and consequently putting high pressure on countries economy. Pakistan mainly depends upon oil and gas resources to fulfil energy requirements. Indigenous resources of Oil are not enough to quench energy thirst of the growing economy. As a result Pakistan has to import large quantity of oil and oil based products from Middle East countries. Gas reserves in the country are enough for current gas requirements. So natural gas is playing a key role in power sector [3].

The US Energy International Agency estimated Pakistan's total oil reserves (unconventional) at 227 Billion barrels of which 9.1 Billion barrels are technically recoverable with today's technology. In recent years, oil recovery remains to be a challenge in the world. Currently, most countries and regions in the world commonly use chemical method to increase oil production of the middle and later stage oil wells [4]. This challenge becomes an opportunity for deployment of tertiary recovery mechanism i.e. Enhanced Oil Recovery (EOR) technologies that will mitigate the energy crises [5]. Therefore, this paper presents the viability of China-Pakistan cooperation in term of installing EOR technologies, its impact on the region and also correlates it with the Pakistan's oil fields to enhance its production in an optimum way.

\section{Enhanced Oil Recovery}

The terms EOR and IOR have been used loosely and interchangeably at times. Improved oil recovery (IOR), is a general term which implies improving oil recovery by any means. For example, operational strategies, such as infill drilling and horizontal wells, improve vertical and areal sweep, leading to an increase in oil recovery. Enhanced oil recovery, or EOR, is more specific in concept, and it can be considered as a subset of IOR. EOR implies a reduction in oil saturation below the residual oil saturation. Recovery of oils retained due to capillary forces (after a water flood in light oil reservoirs), and oils that are immobile or nearly immobile due to high viscosity (heavy oils and tar sands) can be achieved only by lowering the oil saturation below Sor. Miscible processes, chemical floods and steam based methods are effective in reducing residual oil saturation, and are hence EOR methods [6]. 
In recent years, a new set of oil recovery methods known as enhanced oil recovery (EOR) being introduced, uses chemicals such as surfactants, emulsifiers, polymers, acids, dispersants, and solvents have been in conjunction with the secondary recovery techniques in abandoned oil fields to improve crude oil yield, as well as for bioremediation efforts after oil spills [7]. However, these methods carry with them their own inherent risks in addition to the economic costs; the chemical pathways through which these products are generated often use toxic chemicals, such as ethylene oxide in the production of nonionic surfactants $[8,9]$.

USA is the first country that puts ultrasonic oil production technique into practice in the 50s. Since then, several highpower down hole tools used for EOR have been developed in the former Soviet Union and America [4]. Ultrasonic oil production technique, according to $[9,10]$, is one of the most promising methods that met the requirement of high adaptability, simple operation, low cost and no pollution to environment.

\section{China Expertise in EOR}

China is poorly endowed with oil and gas. Its share of the world's oil and gas reserves amount to only 2.3 and 0.9 per cent respectively [11]. As one of Enhanced Oil Recovery techniques, ultrasonic oil production technique has other several advantages, such as high adaptability, simple operation, low cost and zero pollution. China is the third country, following the United States and Russia that masters the ultrasonic oil production technique, and has made great progress in this technique through decades of development [4].

Based on the development of ultrasonic down hole tools for EOR in America and Russia, a series of equipment for ultrasonic oil production have been invented in China. In 2004, ZYQZ type down hole tool for inhibiting super-strong paraffin and reducing antiscaling viscosity was invented by Hanwei Petroleum Machinery Research Institute. It is mainly composed of three parts: vortex, fluidic and sonic-wave technologies. It has been widely put into practice in many oil fields (Zhongyuan oilfield, Shengli oilfield and Huabei oilfield) in China. Application results showed that the average oil recovery can be increased by 6-9\%. In addition, paraffin deposition and antiscaling viscosity of crude oil can be inhibited and reduced effectively [12].

\section{Need of Cooperation}

Recently, Pakistan and China signed a mega project called as China-Pakistan Economic Corridor (CPEC), as an endorsement and continuation to the enhancing bilateral friendly ties between the two countries. The CPEC project is being viewed as the core economic driver not only for the states involved but also for the region as well. Regional connectivity and economic development are two major aspects of the project [13]. The China-Pakistan Economic Corridor (CPEC) project epitomizes the growing mutuality of interest and the vision of a shared politico-economic future on the part of Pakistan and China. It creates a new framework of interaction on the basis of economic connectivity and regional cooperation which will have far reaching positive implications for the two countries as well as the adjoining regions [14].

Nasir (2018) reported that Pakistan and China have decided to strengthen cooperation in oil and gas and power sectors under the Long Term Plan of China-Pakistan Economic Corridor projects. Under the Plan, both countries will also focus on promoting the construction of major projects of thermal power, hydropower, coal gasification and renewable power generation, and supporting power transmission networks. Pakistan and China have also agreed to collaborate in research on the integrated vision. The proposal is also under consideration to establish oil refineries and storages along the CPEC route. The document said that it was agreed by both the countries to utilize Pakistan's own coal for power plant and developing technologies for surface coal gasification, expansion and augmentation of coal mining sector [15].

\section{Conclusion}

Energy crises in Pakistan has been increasing day by day and enhancement to recovery options is the only choice to mitigate this challenge. Pakistan is currently encountering the problems in the shortage of oil \& gas, since many oil and gas fields lack the efficient use of the advanced technique of recovery i.e. Enhanced Oil Recovery. In this perspective, the suggested support needed by China for EOR implementation in Pakistan's fields, will help in mitigating the current energy crisis. That is why Enhanced oil Recovery can be considered as the solution to this problem. Both of the countries can also cooperate in exploring new petrochemical reserves fields which are currently undiscovered due to shortage of advanced technology for oil exploration.

\section{References}

1. Nolan P, Zhang J (2003) Globalization Challenge for Large Firms from Developing Countries: China's Oil and Aerospace Industries. European Management Journal 21(3): 285-299.

2. Islam M (1991) Petrochemical industry in Pakistan. Economic Review.

3. Ahmad A, Jha MK (2008) Status of petroleum sector in Pakistan: A review. Oil and gas business.

4. Wang Z, Xu Y (2015) Review on application of the recent new high-power ultrasonic transducers in enhanced oil recovery field in China. Energy 89: 259-267.

5. Zahid AA, Khan JUR, Siddiqui MU, Rahman SRU (2015) Enhancement to recovery options as a solution in alleviation of the energy crisis. $1^{\text {st }}$ National Petro-Contest.

6. Thomas S (2008) Enhanced oil recovery-an overview. Oil \& Gas Science and Technology-Revue de l'IFP 63(1): 9-19.

7. Kosaric N (2001) Biosurfactants and their application for soil bioremediation. Food Technology and Biotechnology 39(4): 295-304.

8. Lynch DW, Lewis TR, Moorman WJ, Burg JR, Groth DH, et al. (1984) Carcinogenic and toxicologic effects of inhaled ethylene oxide and propylene oxide in F344 rats. Toxicol Appl Pharmacol 76(1): 69-84. 
9. Desbene PL, Desmazieres B, Even V, Basselier JJ, Minssieux L, et al. (1987) Analysis of non-ionic surfactants used in tertiary oil recovery. Optimisation of stationary phase in normal phase partition chromatography. Chromatographia 24(1): 857-861.

10. Dyblenko VP, Kamalov RN, Sharifullin RJ, Tufanov IA (2000) Increase of the Productivity of Wells Using Vibro Wave Treatment. Nedra, Moscow.

11. BP (2001) Statistical Review of World Energy (2000). China Petroleum Economist pp. 18-19.

This work is licensed under Creative Commons Attribution 4.0 Licens

DOI: 10.19080/RAPSCI.2018.04.555636
12. Wang Z, Yin C (2017) State-of-the-art on ultrasonic oil production technique for EOR in China. Ultrason Sonochem 38: 553-559.

13. Cheema ZN (2015) Geostrategic importance of China-Pakistan economic corridor: foreign policy news.

14. Rizvi HA (2015) The China-Pakistan Economic Corridor: Regional Cooperation and socio-Economic Development. Strategic Studies 34(4): 1-17.

15. U.S. Energy Information Administration (EIA), report released in June 2013 estimates Pakistan's total unconventional Reserves.

Your next submission with Juniper Publishers will reach you the below assets

- Quality Editorial service

- Swift Peer Review

- Reprints availability

- E-prints Service

- Manuscript Podcast for convenient understanding

- Global attainment for your research

- Manuscript accessibility in different formats

( Pdf, E-pub, Full Text, Audio)

- Unceasing customer service

Track the below URL for one-step submission https://juniperpublishers.com/online-submission.php 